\title{
Building resilience in post-conflict disaster contexts: children and transitional justice
}

Book or Report Section

Accepted Version

Bisset, A. (2016) Building resilience in post-conflict disaster contexts: children and transitional justice. In: Breau, S. C. and Samuel, K. L. H. (eds.) Research Handbook on Disasters and International Law. Research Handbooks in International Law. Edward Elgar, Cheltenham, pp. 479-500. ISBN 9781784717391 Available at https://centaur.reading.ac.uk/71222/

It is advisable to refer to the publisher's version if you intend to cite from the work. See Guidance on citing.

Publisher: Edward Elgar

All outputs in CentAUR are protected by Intellectual Property Rights law, including copyright law. Copyright and IPR is retained by the creators or other copyright holders. Terms and conditions for use of this material are defined in the End User Agreement.

\section{www.reading.ac.uk/centaur}

\section{CentAUR}


Central Archive at the University of Reading

Reading's research outputs online 


\section{Building Resilience in Post-Conflict Disaster Contexts:}

\section{Children and Transitional Justice}

\section{Introduction}

Children $^{1}$ are among those most negatively affected by conflict related disasters. ${ }^{2}$

Some are the direct victims of shootings, landmines and bombardment. Some witness the killing of family and friends. Many more suffer displacement, lose their homes and access to schooling and are deprived of food and health care. The vulnerability of children, rather than marking them out for protection, all too frequently makes them a target for abduction, trafficking, sexual violence and unlawful recruitment as child soldiers. ${ }^{3}$ The numbers involved are staggering. In the last decade, it is estimated that more than 2 million children died as a direct result of armed conflict, more than 6 million have been permanently disabled or seriously injured, and more than 1 million have been orphaned or separated from their families. ${ }^{4}$ As of 2013 , one billion children were living in conflict-affected countries. Seven million children were refugees and up to 13 million were internally displaced. 28.5 million conflict-affected children were out of primary education and there were 250,000 child soldiers. ${ }^{5}$

\footnotetext{
${ }^{1}$ Children are defined here as those under 18 years in accordance with art 1 , United Nations Convention on the Rights of the Child, General Assembly Resolution 44/25, 20 November 1989, entered into force 2 September 1990.

${ }^{2}$ For the definition of disasters adopted in this chapter see Section 2 below.

${ }^{3}$ UNICEF, Machel Study 10 Year Strategic Review, Children and Conflict in a Changing World, 2009, 3.

${ }^{4}$ UNICEF, "UNICEF's Role in Emergencies" 26 May 2012,

$<$ http://www.unicef.org/emerg/index_33296.html >, accessed 20 May 2015.

${ }^{5}$ European Commission, Humanitarian Aid and Civil Protection, Children in Conflict - ECHO Factsheet, 2014, available at http://ec.europa.eu/echo/files/aid/countries/factsheets/thematic/children_conflict_en.pdf, accessed 16 May 2015.
} 
The impact of war and episodes of widespread violence upon children extends well beyond the period of actual conflict. Children who have undergone traumatic conflict-related experiences often develop anxiety and depression. ${ }^{6}$ Exposure to conflict affects their values, political beliefs and ability to function as future leaders and decision-makers. ${ }^{7}$ Post-conflict societies typically suffer from poverty, a lack of educational facilities and limited health and social protection systems. The absence of effective state institutions disproportionately impacts children, hampering their shortterm development as well as their future prospects. In many post-conflict countries, age pyramids are skewed and children and youth ${ }^{8}$ make up over half of the population. ${ }^{9}$ Thus, in post-conflict contexts, children become key stakeholders. Along with adult members of society, they have suffered the violence of the past, but, as the next generation, they will inherit and must progress the results of post-conflict agreements and initiatives. They therefore occupy a pivotal position in the reconstruction, reconciliation and long-term stability of post-conflict states. It is perhaps surprising then that children have typically been underrepresented in post conflict recovery schemes.

This chapter is concerned with the promotion and protection of children's rights in post-conflict disaster contexts, with a particular focus on the contribution of transitional justice mechanisms to delivering improvements in respect for and

\footnotetext{
${ }^{6}$ Kathleen Kostelny and Michael Wessels, 'Children and Youth in Conflict and Post-Conflict Societies: From Plights of War to Paths of Peacebuilding', in Albrecht Schnabel and Anara Tanyshalieva (eds) Escaping Victimhood: Children, Youth and Post-Conflict Peacebuilding (United Nations University Press 2013), 74.

${ }^{7}$ International Criminal Justice and Children, No Peace Without Justice and UNICEF Innocenti Research Centre, September 2002, 31-2.

${ }^{8}$ The UN defines "youth" as persons between 15 and 24. See United Nations Department of Economic and Social Affairs, Definition of Youth Factsheet, $<$ https://undesadspd.org/Youth.aspx $>$ accessed 16 May 2015.

${ }^{9}$ United Nations, Department of Economic and Social Affairs, Population Division, World Population Prospects: The 2012 Revision (2013).
} 
realisation of children's rights. The chapter conceptualizes transitional justice as one means of building sustainable peace in post-conflict states, making it an important element of durable solution promotion in conflict-related disaster contexts. Within this, children play a vital role as they will ultimately become responsible for the implementation of policies and practices that will ensure, or indeed risk, long term peace and stability. It is therefore essential that they are a principal focus of postconflict transitional justice mechanisms.

The chapter begins by considering the international legal frameworks that ensure the rights of children in post-conflict settings and the corresponding obligations of states. It will explore the relationship between transitional justice and international disaster response/relief law, demonstrating their complementary aims and objectives, and examine the role of children in post-conflict disaster contexts. It will then move to analyse the involvement of children and the protection and promotion of their rights within transitional justice practice to date. The chapter will argue that if transitional justice mechanisms are to fulfill their potential and make a meaningful contribution to building resilience to future conflict related disasters, they must adopt and integrate a rights-based approach to children, ensure their participation in learning the lessons of the past, and reflect their needs and interests in post-conflict settlements.

\section{The Legal Protection of Children in Post-Conflict Disaster Contexts}


The extent to which international disaster response/relief principles are considered to apply to humanitarian emergencies arising from conflict is contested. ${ }^{10}$ The International Law Commission (ILC) and the International Federation of Red Cross and Red Crescent Societies (IFRC), the two international organisations at the forefront of the development of international disaster response/relief law (IDRL), take different approaches. The IFRC does not consider emergencies which flow from armed conflict to fall within the purview of IDRL due to the existence of the comprehensive framework of international humanitarian law (IHL) governing humanitarian assistance in conflict. This, the IFRC believes, is the responsibility of the International Committee of the Red Cross. ${ }^{11}$ In contrast, the ILC Draft Articles on the Protection of Persons in the Event of Disasters are more flexibly drafted, noting only that the articles "do not apply to situations to which the rules of international humanitarian law are applicable". ${ }^{12}$ They therefore allow for emergencies flowing from conflict to be encompassed within IDRL where appropriate. ${ }^{13}$ This chapter adopts the approach and reasoning of the ILC in this respect, rationalizing that to exclude the applicability of the draft articles to complex emergencies because of the coexistence of an armed conflict is to undermine the principle of protection of persons in the event of a disaster. ${ }^{14}$ It considers conflict situations and their consequences to fall within the ambit of IDRL.

\footnotetext{
${ }^{10}$ Emika Tokunaga, 'Evolution of International Disaster Response Law: Toward Codification and Progressive Development of the Law', in David D Caron, Michael J Kelly and Anastasia Telesetsky (eds) The International Law of Disaster Relief, (CUP 2014), 61.

${ }^{11}$ IFRC, Law and Legal Issues in International Disaster Response: A Desk Study, (2007), 24. The IFRC considers conflict situations only tangentially when disasters occur in the context of conflict, IFRC Desk Study, Ch. 15.

${ }^{12}$ International Law Commission, Protection of Persons in the Event of Disasters, Text and Titles of the Draft Articles adopted by the Drafting Committee on First Reading, A/CN.4/L.831, 15 May 2014, art. 21[4].

${ }^{13}$ See Andrea de Guttry, 'Surveying the Law', in Andrea de Guttry, Marco Gestri and Gabriella Venturini, (eds), International Disaster Response Law, (TMC Asser Press 2012), 10.

${ }^{14}$ Marcelo Vázquez Bermúdez, "Statement of the Chairman of the Drafting Committee on Protection of Persons in the Event of Disasters", 31 July 2009, 14.
} 
There is no central legal treaty regime regulating international disasters ${ }^{15}$ and certainly no instrument(s) that relates to the situation of children in conflict related disasters specifically. Instead, IDRL largely builds upon existing international customary and conventional law. ${ }^{16}$ The IFRC Desk Study identifies numerous international legal frameworks as relevant and related to IDRL, including international human rights law, international humanitarian law (IHL) and international criminal law, among others. ${ }^{17}$ Few of these make specific mention of disaster settings. ${ }^{18}$ Yet, together, they contain a wealth of rights, obligations and standards of protection for children affected by conflict.

While this chapter is concerned with post-conflict settings, and IHL is generally regarded as applicable during armed conflict, the fragility and turbulence of post-conflict zones means that there may be no clear distinction between armed conflict and peace. There is very frequently relapse into violence, bringing back the applicability of IHL in what might overall be considered "post-conflict" settings. This makes IHL relevant to post-conflict disaster discourse. Under IHL, children benefit from the general protective provisions afforded to civilians living within conflict areas. ${ }^{19}$ In addition, the Geneva Conventions and their Additional Protocols include

\footnotetext{
${ }^{15}$ IFRC Desk Study (n 11) Ch. 3

${ }^{16}$ Gabriella Venturini, 'International Disaster Response Law in Relation to Other Branches of International Law' in de Guttry (n 13) 47.

17 IFRC, Law and Legal Issues in International Disaster Response, (2007), 34-52.

${ }^{18}$ Exceptions include African Charter on the Rights and Welfare of the Child, OAU Doc. CAB/LEG/24.9/49 (1990), entered into force Nov. 29, 1999, art 23; International Convention on the Rights of Persons with Disabilities, General Assembly Resolution 61/106,13 December 2006, entered into force 3 May 2008, art 11.

${ }^{19}$ See particularly: Fourth Geneva Convention relative to the Protection of Civilian Persons in Time of War (12 August 1949); Additional Protocol I to the Geneva Conventions Relating to the Protection of Victims of International Armed Conflicts (8 June 1977) (API); and Additional Protocol II to the Geneva Conventions Relating to Victims of Non International Armed Conflicts (8 June 1977) (APII).
} 
provisions related to the treatment of children during armed conflict, ${ }^{20}$ including the provision of education, ${ }^{21}$ evacuation, ${ }^{22}$ family reunification and care of unaccompanied children, ${ }^{23}$ safety zones and the free passage of consignments intended for children. ${ }^{24}$ There is regulation of their participation in hostilities ${ }^{25}$ and prohibition of recruitment into armed forces and groups below the age of 15 years. ${ }^{26}$ Girls are to be protected from crimes of sexual violence ${ }^{27}$ and all parties to conflict are required to provide children with the care and aid they may need because of their age. $^{28}$

Under international criminal law, many of the violations of children's rights that occur during conflict constitute offences and attract individual criminal responsibility. Forcibly transferring children of the group to another group or undertaking measures designed to prevent births, carried out with the intent to destroy, in whole or in part, a national, ethnical, racial or religious group as such amounts to the crime of genocide. ${ }^{29}$ When widespread and systematic and committed against civilian, including child, populations pursuant to an organizational policy, murder, extermination, enslavement, torture, persecution, deportation or forcible transfer of a population, enforced disappearance, apartheid and crimes of sexual violence constitute crimes against humanity under the Rome Statute of the

\footnotetext{
${ }^{20}$ API, art 77; APII, art 4(3).

${ }^{21}$ APII, art 4(3).

${ }^{22}$ Fourth Geneva Convention, arts 14, 17 and 24; API, art 78; and APII, art 4(3)(e).

${ }^{23}$ Fourth Geneva Convention, arts. 24-26, 50 and 82; API, arts 74-76; and APII, arts 4 and 6.

${ }^{24}$ Fourth Geneva Convention, arts 23, 14 and 17.

${ }^{25}$ API, art 77.

${ }^{26}$ APII, art 4(3).

${ }^{27}$ Fourth Geneva Convention, art 27.

${ }^{28}$ API, art 77. On the shortcomings of IHL from a child rights perspective see Vesselin Popovski, 'Protection and Participation of Children in Post-Conflict Peacebuilding: International Law and Evolving Practice', in Schnabel (n 6) 116-118.

${ }^{29}$ Convention on the Prevention and Punishment of the Crime of Genocide, 9 December 1948, art 2; Rome Statute of the International Criminal Court, A/Conf.183/9, 17 July 1998, entered into force 1 July 2002, art 6.
} 
International Criminal Court. ${ }^{30}$ Enslavement is understood to encompass trafficking, particularly of women and children. ${ }^{31}$ Intentional attacks on schools, ${ }^{32}$ crimes of sexual violence, using starvation as a method of warfare and using children under 15 as soldiers amount to war crimes when committed in the context of an armed conflict. ${ }^{33}$ The International Labour Organisation lists the recruitment of under $18 \mathrm{~s}$ as one of the worst forms of child labour and calls for its prohibition under national law. ${ }^{34}$

The broadest and furthest reaching protection of children's rights comes from international human rights law, and in particular the UN Convention on the Rights of the Child (CRC). ${ }^{35}$ The Convention enjoys near universal ratification ${ }^{36}$ and obligates states parties to respect and ensure to all children within their jurisdiction ${ }^{37}$ a full range of civil, political, economic, social and cultural rights. It is underpinned by four guiding principles: non-discrimination, ${ }^{38}$ the best interests of the child, ${ }^{39}$ the right to

\footnotetext{
${ }^{30}$ Rome Statute, art 7.

${ }^{31}$ International Criminal Court, Elements of Crimes, UN Doc. PCNICC/2000/1/Add.2 (2000), art 7(1)(c), fn 11.

${ }^{32}$ See Prosecutor v Kordic and Cerkez, Judgement, IT-95-14/2-T, 26 February 2001.

${ }^{33}$ Rome Statute, art 8 . The crime of using starvation as a method of warfare only applies in international armed conflicts. The others apply in both international and non-international armed conflicts. Recruitment of child soldiers, killing or maiming, rape or other forms of sexual violence, abduction, attacks on schools or hospitals and denial of humanitarian assistance are also considered grave violations against children by the UN Security Council. Recruitment of child soldiers, killing, maiming and sexual violence trigger the monitoring and reporting mechanism, which is designed to contribute to the prevention of violations and protection of children. See UNSC Resolution 1612 (2005); UNSC Resolution 1882 (2009); Office of the Special Representative of the Secretary General for Children in Armed Conflict, The Six Grave Violations against Children in Armed Conflict: The Legal Foundation, Working Paper No. 1, October 2009 (updated November 2013).

${ }^{34}$ International Labour Organisation, C182 Concerning the Prohibition and Immediate Action for the Elimination of the Worst Forms of Child Labour, 1999; International Labour Organisation, Recommendation 190 Concerning the Prohibition and Immediate Action for the Elimination of the Worst Forms of Child Labour, 1999.

${ }^{35}$ United Nations Convention on the Rights of the Child, General Assembly Resolution 44/25, 20

November 1989, entry into force 2 September 1990.

${ }^{36}$ Only the USA and Somalia are non-states parties.

${ }^{37}$ Art 2.

${ }^{38}$ Ibid.

${ }^{39}$ Art 3.
} 
life, survival and development, ${ }^{40}$ and the right to be heard. ${ }^{41}$ The Convention contains no general derogation clause, meaning that the rights of children are to be respected at all times, including during public emergencies and armed conflict.

The CRC contains important protections against violence, neglect and abuse, ${ }^{42}$ trafficking ${ }^{43}$ and from economic ${ }^{44}$ and sexual exploitation ${ }^{45}$, to which children are vulnerable both during and after conflict, particularly if separated from family. States parties are under obligations to protect all children affected by armed conflict ${ }^{46}$ and to take all appropriate measures to promote their physical and psychological recovery post conflict. ${ }^{47}$ With regard to economic, social and cultural rights, states parties are required to take measures to the maximum extent of their available resources. ${ }^{48} \mathrm{UN}$ bodies have consistently stressed the indivisibility and interdependence of human rights and have emphasized that progressive realization of economic, social and cultural rights should not be misinterpreted to deprive the obligation of meaningful content but should be moved towards with deliberate, concrete and targeted steps. ${ }^{49}$ States parties are required to be proactive and to take all possible measures ${ }^{50}$ in providing children with the rights to education, ${ }^{51}$ the highest attainable standard of

\footnotetext{
40 Art 6.

${ }^{41}$ Art 12. Committee on the Rights of the Child, General Comment No. 5 (2003), General Measures of Implementation of the Convention on the Rights of the Child (Art's 4, 42 and 44, para 6), CRC/GC/2003/5, 27 November 2003, para 12.

${ }^{42}$ Art 19.

43 Art 11(1)

${ }^{44}$ Art 32.

${ }^{45}$ Art 34

${ }^{46}$ Art 38

${ }^{47}$ Art 39

${ }^{48}$ Art 4.

${ }^{49}$ CESCR General Comment No. 3, para 2; Committee on the Rights of the Child, General Comment No. 15 (2013) on the Right of the Child to the Enjoyment of the Highest Attainable Standard of Health (Art. 24), CRC/C/GC/15, 17 April 2013, para 7.

${ }^{50}$ General Comment No. 5 (2003) (n 40) paras 5-8.

${ }^{51}$ Arts 28 and 29.
} 
health, freedom from disease and malnutrition, access to clean drinking water, ${ }^{52}$ social security, ${ }^{53}$ a standard of living adequate for physical, mental, spiritual, moral and social development ${ }^{54}$ and to rest, play and leisure. ${ }^{55}$ The equal importance given to economic, social and cultural rights is important within transitional contexts, where many children continue to be exposed to poverty, hunger and a lack of access to health care and education. ${ }^{56}$

The Optional Protocol on the Involvement of Children in Armed Conflict reinforces the CRC general prohibition on the use of under $15 \mathrm{~s}$ in armed hostilities ${ }^{57}$ and raises the age limit to 18 years. ${ }^{58}$ Children who have undertaken an active part in hostilities are to be demobilized and receive such assistance as is necessary for their recovery, rehabilitation and reintegration. ${ }^{59}$ Similarly, the Optional Protocol on the Sale of Children, Child Prostitution and Child Pornography strengthens the general CRC duty to prevent the sexual exploitation of children, imposing obligations on state parties in relation to a wide range of exploitative sexual practices to which children, particularly in post-conflict settings, may be vulnerable. ${ }^{60}$

Soft law sources also recognise the rights of and need to protect children within disaster contexts, especially those related to conflict. The Guiding Principles

\footnotetext{
52 Art 24.

53 Art 26

${ }^{54}$ Art 27.

${ }^{55}$ Art 31

${ }^{56}$ Saudamini Siegrist, 'Child Rights and Transitional Justice', in Sharanjeet Parmar and others (eds) Children and Transitional Justice: Truth Telling, Accountability and Reconciliation, (UNICEF and Human Rights Programme, Harvard Law School 2010), 7.

${ }^{57}$ Art 38;

${ }^{58}$ Optional Protocol to the Convention on the Rights of the Child on the Involvement of Children Armed Conflict, A/Res/54/263, 25 May 2000, entered into force 12 February 2002.

${ }^{59}$ Arts 6(3) and 7.

${ }^{60}$ Optional Protocol to the Convention on the Rights of the Child on the Sale of Children, Child Prostitution and Child Pornography, General Assembly Resolution A/RES/54/263, 25 May 2000, 18 January 2002.
} 
on Internal Displacement afford children special levels of protection and assistance in the event of displacement, ${ }^{61}$ prohibit their forced labour ${ }^{62}$ and participation in hostilities ${ }^{63}$ and guarantee education ${ }^{64}$ and expedited reunification in the event of separation from family. ${ }^{65}$ The Cape Town and Paris Principles, primarily concerned with children associated with armed groups and armed forces (CAAFAG), constitute globally accepted norms on the immediate, medium and long-term standards of best practice in relation to affected children. ${ }^{66}$ The Millennium Declaration includes an international commitment to assist and protect children affected by armed conflict. ${ }^{67}$ This was further emphasized at the Millennium Summit, which reaffirmed the need to promote and protect the rights of children in armed conflict, to ensure their receipt of timely and effective humanitarian assistance and to provide for their education, rehabilitation and reintegration into society. ${ }^{68}$ The UN Security Council, ${ }^{69}$ General Assembly ${ }^{70}$ and Economic and Social Council ${ }^{71}$ have repeatedly adopted resolutions and issued reports calling for the safeguarding of children's rights both during and after conflict, recognizing the protection of children as a key aspect of humanitarian assistance, conflict resolution and development.

\footnotetext{
${ }^{61}$ Principle 4.

62 Principle 11.

63 Principle 13.

${ }^{64}$ Principle 23.

65 Principle 17.

${ }^{66}$ Cape Town Principles and Best Practices on the prevention of the recruitment of children into the armed forces and on the demobilization and reintegration of child soldiers in Africa, April 1997; The Paris Principles, Principles and Guidelines on Children Associated with Armed Forces or Armed Groups, February 2007.

${ }^{67}$ United Nations Millennium Declaration, A/Res/55/2/, 8 September 2000, para 26.

${ }^{68} 2005$ World Summit Outcome, A/Res/60/1, 25 October 2005, para 117.

${ }^{69}$ Security Council Resolutions 1261 (1999), 1314 (2000), 1379 (2001), 1460 (2003), 1539 (2004), 1612 (2005), 1882 (2009), 1998 (2011) and 2068 (2012).

${ }^{70}$ UN General Assembly Declaration, A World Fit For Children, appended to A/Res/S-27/2 (2002); UN General Assembly Resolution, Rights of the Child, A/Res/62/141 (2008), UN General Assembly, Right of the Child, A/Res/63/241 (2009).

${ }^{71}$ Report of the Economic and Social Council for 1999, A/54/3/Rev.1, Part VI Humanitarian Affairs, paras 21-2.
} 
There is, therefore, a wealth of hard and soft law aimed at the protection of children and ensuring their rights in post-conflict disaster contexts. The remainder of this chapter examines the mechanisms designed to respond to violations of children's rights and the contribution these can make to the reconstruction and long-term stability of post-conflict states.

\section{The Relationship between Transitional Justice and International Disaster}

\section{Response}

As discussed, the focus of this Chapter is on the recovery and restoration phase of IDRL ${ }^{72}$ defined as 'the restoration, and improvement where appropriate, of facilities, livelihoods and living conditions of disaster-affected communities, including efforts to reduce disaster risk factors". ${ }^{73}$ In recent years, the UN has consistently drawn attention to the need for a long-term focus in disaster relief, stressing the connection between rehabilitation and development and calling for assistance to be provided in a way that will be supportive of long term recovery. ${ }^{74}$ Where that recovery is from conflict, it has been recognized that a comprehensive approach is needed and that all efforts, including those aimed at political stabilization and peace building, ${ }^{75}$ are important in reconstruction and development. ${ }^{76}$ If IDRL is

\footnotetext{
${ }^{72}$ On the phases of IDRL see de Guttry (n 13) 8.

${ }^{73}$ Glossary of the International Recovery Platform, <http://www.recoveryplatform.org/resources/glossary/R > accessed 16 May 2015.

${ }^{74}$ UNGA, Strengthening of the Coordination of Humanitarian Emergency Assistance of the United Nations, A/Res/46/182, 19 December 1991, para 9; UNGA, Humanitarian Assistance in the Field of Natural Disasters from Relief to Development, A/Res/54/233, 26 February 2000; UNGA, Strengthening of the Coordination of Humanitarian Emergency Assistance of the United Nations, A/Res/68/102, 13 December 2013, para 25.

${ }^{75}$ In 2007, the UN Secretary-General's policy committee adopted the definition of "a range of measures targeted to reduce the risk of lapsing or relapsing into conflict, to strengthen national capacities at all levels for conflict management, and to lay the foundations for sustainable peace and
} 
concerned not only with the provision of immediate relief but equally with building resilience to future disasters, in post-conflict contexts peace building initiatives must occupy a significant position within the IDRL framework. Studies show that without serious efforts to implement sustainable peace, conflict is likely to recur within ten years. ${ }^{77}$ For this reason, at UN level conflict prevention, peace building and sustainable and equitable development have become entwined and are viewed as mutually reinforcing activities. ${ }^{78}$

There is, therefore, a complex relationship between disaster recovery, peace building and development in post conflict contexts. It is within this complicated set of connections that transitional justice becomes relevant to the IDRL framework. Transitional justice is concerned with the strategies employed to deal with past human rights abuses in countries moving from conflict or repressive regime to democratic rule in order to ensure accountability, serve justice and achieve reconciliation". ${ }^{79}$ Advocates of transitional justice argue that dealing with the past is essential to longterm peacebuilding. Failure to pursue accountability, it is claimed, undermines the rule of law, ${ }^{80}$ the rights and needs of victims, ${ }^{81}$ and perpetuates cycles of violence. ${ }^{82}$ The transitional justice framework utilises prosecutions, truth commissions,

development”, quoted in Erin McCandless, 'Lessons from Liberia: Integrated Approaches to Peacebuilding in Transitional Settings', Occasional Paper 160, (Institute for Security Studies 2008), 2. ${ }^{76}$ Report of the Economic and Social Council for 1999, A/54/3/Rev.1, Part VI Humanitarian Affairs, paras 10 and 17.

${ }^{77}$ Karen Brounéus, Reconciliation: Theory and Practice for Development Cooperation, (Swedish International Development Cooperation Agency 2003).

${ }^{78}$ Prevention of Armed Conflict: Report of the Secretary-General, UN Doc. A/55/985-S/2001/574, (7 June 2001), para 114; A More Secure World: Our Shared Responsibility: Report of the SecretaryGeneral's High-Level Panel on Threats, Challenges and Change (UN 2004).

${ }^{79}$ Report of the UN Secretary General on the Rule of Law and Transitional Justice in Conflict and Post Conflict Societies, S/2004/616, 23 August 2004, para 8.

${ }^{80}$ Luc Huyse, 'Amnesty, Truth or Prosecution in Luc Reychler and Thania Paffenholz (eds) PeaceBuilding. A Field Guide, (Lynne Rienner 2001), 325.

${ }^{81}$ Priscilla B Hayner, Unspeakable Truths: Confronting State Terror and Atrocity, (Routledge 2001), 28.

${ }^{82}$ Report of the UN Secretary General on the Rule of Law and Transitional Justice (n 79) para 2. 
reparations and reforms, among other measures, ${ }^{83}$ to meet the diverse needs of transitional states, contribute to a sustainable peace, and bring about healing, repair and reconciliation. ${ }^{84}$

In post-conflict disaster contexts that have involved serious violations of human rights, international human rights law stipulates that victims, including child victims, have rights to justice, truth, reparation and non-recurrence, and places corresponding obligations upon states. These rights and obligations correspond to the mechanisms of transitional justice discussed above. Trials enable states to fulfil their obligation to investigate and punish the perpetrators of human rights violations and provide victims with their right to justice and an effective remedy. Fact-finding investigations are a means by which states implement their duty to investigate and identify perpetrators and thereby provide victims, their families and the wider society with the right to know or the right to truth. Through reparations states fulfil their obligation to provide restitution and compensation to victims and provide them with their right to reparation. Finally, justice reforms allow a state to implement its duty to take effective measures to prevent future violations and thereby guarantee the right of non-repetition. ${ }^{85}$

At one time, transitional justice was considered to focus purely on addressing past human rights abuses, typically civil and political violations, and to be concerned

\footnotetext{
${ }^{83}$ Ibid para 8.

${ }^{84}$ Charles Villa-Vicencio and Erik Doxtader, Pieces of the Puzzle: Keywords on Reconciliation and Transitional Justice, (Institute for Justice and Reconciliation 2004), 72.

${ }^{85}$ See Louis Joinet, Set of Principles for the Protection and Promotion of Human Rights Through Action to Combat Impunity, UN Doc. E/CN.4/Sub.2/1997/20/Rev.1 (1997) [Joinet Principles], updated by Dianne Orentlicher, Updated Set of Principles for the Protection and Promotion of Human Rights Through Action to Combat Impunity, UN Doc. E/CN.4/2005/102.Add.1 (2005) [Updated Principles] and Basic Principles and Guidelines on the Right to a Remedy and Reparation for Victims of Violations of International Human Rights and Humanitarian Law annexed to General Assembly Res. A/C.3/60/L.24 [Bassiouni Principles].
} 
only with the transition from violence to peace. Increasingly, it is envisaged as one component of a wider peacebuilding and development agenda. ${ }^{86}$ The potential for transitional justice to contribute to and promote sustainable peace is now well documented. ${ }^{87}$ Van Zyl explains that through prosecution, truth recovery and the formulation of reform recommendations transitional processes can expose and address past grievances, promote institutional and security sector reform and inform reparation programs. These initiatives, in turn, contribute to democracy consolidation, inculcation of a rule of law culture and national reconciliation, ${ }^{88}$ laying the foundations for long-term stability and resilience to future conflict.

Yet the linking of transitional justice to peacebuilding, development, and building resilience presents new challenges. Understandings of development have become more sophisticated and it is now envisaged as "freedom from want, freedom from fear and freedom to live in dignity" 89 and as providing all people "the freedom to choose the kind of lives they would like to live, the access to the resources that would make those choices meaningful and the security to ensure that they can be enjoyed in peace". ${ }^{90}$ This in turn requires new ways of thinking about the contribution that transitional justice can make to development and security. It is argued that transitional justice must engage with a broader spectrum of human rights violations

\footnotetext{
${ }^{86}$ The Security Council affirms that 'development, peace and security and human rights are interlinked and mutually reinforcing', UN Security Council Resolution 1674 (2006). Note, however, the perceived tension between transitional justice and peacebuilding, Jemima Garcia-Godos and Chandra Lekha Sriram, 'Introduction' in Chandra Lekha Sriram and others (eds), Transitional Justice and Peacebuilding on the Ground: Victims and Ex-Combatants, (Routledge 2013), 3. ${ }^{87}$ Dustin N. Sharp, 'Beyond the Post-Conflict Checklist: Linking Peacebuilding and Transitional Justice through the Lens of Critique' (2013) 14 Chicago Journal of International Law $<$ http://chicagounbound.uchicago.edu.cjil/vol14/iss1/6> accessed 20 May 2015; Gerhard Thallinger, 'The UN Peacebuilding Commission and Transitional Justice' (2007) 8 German Law Journal 681. ${ }^{88}$ Paul van Zyl, 'Promoting Transitional Justice in Post-Conflict Societies', in Alan Bryden and Heiner Hänggi, (eds), Security Governance in Post-Conflict Peacebuilding, (Geneva Centre for the Democratic Control of Armed Forces 2005), 209-233.

${ }^{89}$ In Larger Freedom: Towards Development, Security and Human Rights for All: Report of the Secretary-General, UN Doc. A/59/2005 (21 March 2005), Annex, para 2.

${ }^{90}$ Ibid para 17.
} 
and consider socioeconomic violations committed before and during conflict and, crucially, use the reform mandate to promote the importance of social justice. ${ }^{91}$ Without social and economic policy reform, it is argued that the goals of reconciliation and sustainable peace cannot be achieved. ${ }^{92}$ Political justice in the form of institutional reform, adherence to the rule of law, creation of a human rights culture and accountable, democratic governance, of course, remain important. ${ }^{93}$ Equally important, however, is the need for socioeconomic justice, which is future focused. ${ }^{94}$ Economic and social policy becomes vital to ensure investment in schools and housing, access to health care and sanitation and availability of jobs. Without the pursuit and delivery of socioeconomic justice alongside political reform, the next generation will suffer the same problems as the previous one and the likelihood of conflict will be heightened, rather than minimized. To be truly transformative $\mathrm{e}^{95}$ and to make a meaningful contribution for the next generation, transitional justice must embrace the economic and social elements of past conflict and move beyond the traditional civil and political paradigm. This revisualization of transitional justice is, therefore, particularly important for children.

\section{Children's Rights and Post-Conflict Transitional Justice}

\footnotetext{
${ }^{91}$ Lisa J Laplante, 'Transitional Justice and Peacebuilding: Diagnosing and Addressing the Socioeconomic Roots of Violence through a Human Rights Framework' (2008) 2 International Journal of Transitional Justice 331, 334-8

${ }^{92}$ Ibid 348-52. See also Roger Duthie, 'Towards a Development Sensitive Approach to Transitional Justice' (2008) 2 International Journal of Transitional Justice 292.

${ }^{93}$ Wendy Lambourne, 'Transitional Justice and Peacebuilding After Mass Violence', (2009) 3 International Journal of Transitional Justice 28, 44-5.

${ }^{94}$ Rama Mani, 'Rebuilding an Inclusive Political Community after War' (2005) 36 Security Dialogue 511; Rama Mani, Beyond Retribution: Seeking Justice in the Shadows of War (Polity Press 2002).

${ }^{95}$ Lambourne (n 93).
} 
Despite the apparent relevance of children within transitional justice and of transitional justice for children, the recognition of children as stakeholders in postconflict settings and settlements has come relatively late. While children are very often the "face" of conflict related disasters, with their images used to mobilise the international community and civil society around relief efforts and donation, ${ }^{96}$ they have seldom been consulted or included in post-conflict decision-making. Too frequently, they have been viewed as objects of charity, as passive and in need of protection. By categorizing children as vulnerable, it becomes easier to mute their voices and down play their needs and interests. ${ }^{97}$ Such an approach overlooks children as rights bearers and fails to acknowledge the important role they can play in postconflict reconstruction.

Both transitional justice ${ }^{98}$ and peacebuilding commentators ${ }^{99}$ acknowledge the need to create inclusive programmes, which take account of the needs and voices of children and youth. This is necessary for a number of reasons. Without the inclusion and consultation of children in transitional programmes, an incomplete account of the nature and impact of the violations suffered by children and how best to address them will be recorded. As children are in their formative years, and more impressionable, exposure to violence and conflict may result in a loss of sense of what is acceptable behavior at individual and societal levels and a consideration that resort to violence is an appropriate means of dispute resolution. In order to halt cyclical, crossgenerational violence, it is essential to include children within transitional justice

\footnotetext{
${ }^{96}$ Jonathan Todres, 'Mainstreaming Children's Rights in Post-Disaster Settings' (2011) 25 Emory International Law Review 1233, 1235.

${ }^{97}$ Schnabel (n 6) 12 and 17.

${ }^{98}$ Parmar (n 56).

${ }^{99}$ Schnabel (n 6).
} 
programmes aimed at reforming social arrangements. ${ }^{100}$ More generally, failure to include children wastes their potential and capacity to further the cause of reconciliation and peacebuilding. As Machel asserts, "unless children themselves are consulted and engaged, we will fall short and undermine the potential to pursue the most relevant and the most durable solutions". ${ }^{101}$ Indeed, recent studies stress the contribution that children can make to their families, communities and societies in conflict, post-conflict and reconstruction processes following emergencies. ${ }^{102}$ This has prompted the UN Committee on the Rights of the Child (the Committee) to recommend that children affected by emergencies should be encouraged and enabled to participate in analyzing their situation and future prospects. ${ }^{103}$ There is, therefore, an emerging consensus that failure to address the concerns of children can undermine the long-term recovery of post-conflict societies and that children must be involved in developing an understanding of the past if they are to pay a constructive role in building the future. ${ }^{104}$

Beyond the discourse on the importance of consulting children from a reconstruction perspective, failure to adopt an inclusive, child-sensitive approach to transitional justice ignores children's status as rights bearing, social actors under the CRC. Specifically, it falls short of the standards set down in Article 12, which stipulates that the child who is capable of forming his or her own views has the right to express those views freely in all matters affecting him or her, with views being

\footnotetext{
${ }^{100}$ Cécile Aptel and Virginie Ladisch, Through a New Lens: A Child Sensitive Approach to Transitional Justice, (International Center for Transitional Justice 2011), 6

${ }^{101}$ UN General Assembly, Impact of Armed Conflict on Children, Report of the Expert of the Secretary General, Ms Graca Machel, UN Doc. A/51/306, 26 August 1996, Foreword, x-xi.

102 See for example, UNICEF, The Participation of Children and Young People in Emergencies. A Guide for Relief Agencies Based Largely on the Experiences in the Asian Tsunami Response, (Bangkok 2007).

${ }^{103}$ Committee on the Rights of the Child, General Comment No. 12 (2009), The Right of the Child to be Heard, CRC/C/GC/12, 20 July 2009, para 125

${ }^{104}$ Aptel and Ladisch (n 100) 4.
} 
given due weight in accordance with age and maturity. ${ }^{105}$ To that end, children are to be given the opportunity to be heard in judicial or administrative proceedings affecting them, either directly or through a representative. ${ }^{106}$ As discussed above, Article 12 is one of the CRC's four general principles, ${ }^{107}$ connected to all other Articles of the Convention, which cannot be fully implemented if the child is not respected as a subject with his or her own views. ${ }^{108}$ It is closely linked with the rights to freedom of expression ${ }^{109}$ and to access information, ${ }^{110}$ which are considered essential prerequisites for the effective exercise of the right to be heard. ${ }^{111}$

The Committee views Article 12 as both an individual and collective right ${ }^{112}$ and has emphasized that States Parties ought to view children as a group with relevant perspectives and experiences that should be considered in decision-making, policymaking and preparation of laws and other measures. ${ }^{113}$ Children are a group with a right to be heard, not only momentarily, but in "intense exchanges with adults" in all relevant contexts of children's lives. ${ }^{114}$ Moreover, the Committee has held that states parties cannot fulfill their obligation of acting in a child's best interests without first meeting the requirements of Article $12 .{ }^{115}$ Article 12 rights do not cease in situations of crisis or in their aftermath. ${ }^{116}$ Indeed, the Committee has stressed that in postconflict contexts, “children's participation helps them to regain control over their

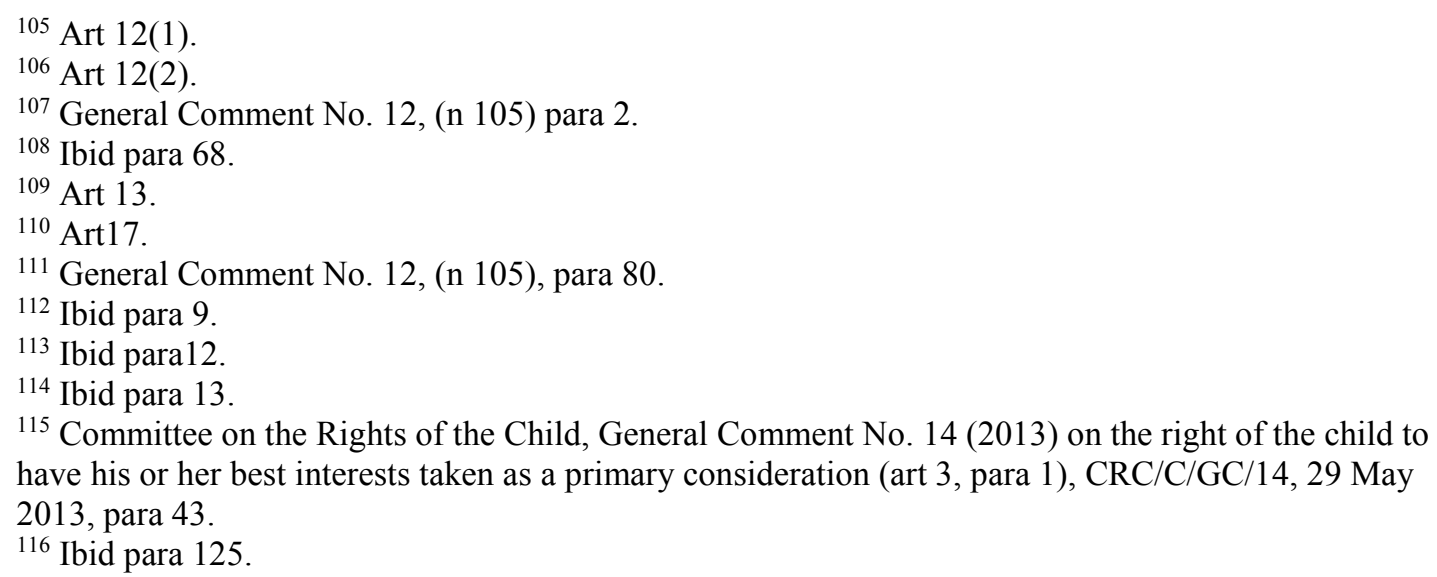


lives, contributes to rehabilitation, develops organizational skills and strengthens a sense of identity". ${ }^{117}$ States parties are therefore encouraged to "support mechanisms which enable children...to play an active role in...post-conflict resolution processes". ${ }^{118}$ In accordance with the non-discrimination principle, this means that all children, including the girl child and children from vulnerable or marginalized groups, must be enabled to participate on an equal basis. ${ }^{119}$

\section{Children in Transitional Justice Practice}

It is clear from the foregoing that alongside the development of legal regimes that aim at the realization of children's rights, a more sophisticated understanding of the importance of children within post-conflict disasters is emerging. Yet work remains to be done in practice if the potential of transitional justice initiatives is to be realized as a means of post-conflict reconstruction for children. The following sections examine the efforts undertaken to implement obligations relating to children across transitional justice practice.

\subsection{Prosecutions}

Prosecution remains a key response to the commission of serious human rights violations. Criminal justice is considered essential to provide redress, assist with

\footnotetext{
117 Ibid.

${ }^{118}$ Ibid para 126.

${ }^{119}$ Ibid paras 75-79.
} 
healing and halt the impunity that threatens sustainable peace. ${ }^{120}$ This is as important for children as for adult populations. Yet despite their frequently widespread and egregious nature, violations of children's rights have historically seen relatively little acknowledgement within international courts and tribunals. Crimes against children attracted some condemnation at the Nuremberg and Tokyo trials ${ }^{121}$ and were treated as aggravating factors in sentencing at the $a d$ hoc tribunals. ${ }^{122}$ It was not until the creation of the Special Court for Sierra Leone that violations suffered by children received meaningful attention when Court became the first to prosecute and convict ${ }^{123}$ for the crime of conscripting or enlisting children under 15 into armed forces or groups or using them to participate actively in hostilities. ${ }^{124}$ The Special Court also prosecuted sexual crimes committed against girls forcibly taken as "bush wives" under the category of "other inhumane acts" 125 constituting crimes against humanity. ${ }^{126}$ This trend has continued at the ICC, where the Court's first trial concerned the war crime of using child soldiers in the DRC. ${ }^{127}$ The ICC has spent considerable energy on crimes related child soldiers during its early years, listing them in seven of the first twelve indictments. ${ }^{128}$ Sexual offences against girls have

\footnotetext{
${ }^{120}$ International Criminal Justice and Children (n 7) 31-2.

${ }^{121}$ Cécile Aptel, 'International Criminal Justice and Child Protection', in Parmar (n 56) 88-9.

122 Prosecutor v Kunarac, Kovac and Vukovic, Judgement, IT-96-23-T and IT-96-23-T/1, 22 February 2001, Part VI; Prosecutor v Kristic, Judgment, Case No. IT-98-33-T, 2 August 2001; Prosecutor v Akayesu, Case No. ICTR-96-4-T, Judgment, 2 September 1998.

${ }^{123}$ Prosecutor v Fofana and Kondewa, Judgment, SCSL-01-14-T, 2 August 2007; Prosecutor v Brima, Kamara and Kanu, Judgment, SCSL-04-16-T, 20 June 2007; Prosecutor v Taylor, Judgment, SCSL03-01-T- 1283, 26 April 2012.

${ }^{124}$ Statute of the Special Court for Sierra Leone, art 4(c).

125 Statute of the Special Court for Sierra Leone, art 2(i).

${ }^{126}$ Prosecutor v Brima, Kamara and Kanu, Appeals Judgment, SCSL-2004-16-A, 22 February 2008. The court's treatment of this crime as a type of forced marriage has attracted criticism for failure to capture the criminal nature of the relationship. See Augustine SJ Park, "“Other Inhumane Acts": Forced Marriage, Girl Soldiers and the Special Court for Sierra Leone' (2006) 15 Social and Legal Studies 315.

${ }^{127}$ Prosecutor v. Thomas Lubanga Dyilo, Judgment pursuant to Article 74 of the Statute, ICC-01/0401/06, 14 March 2012.

${ }^{128}$ See the indictments of Joseph Kony, Vincent Otti, Okot Odhiambo, Bosco Ntaganda, Germain Katanga and Matthieu Ngudjolo Chui $<$ http://www.icc-cpi.int $>$ accessed 4 July 2015.
} 
also been charged. ${ }^{129}$ However, at the national level less has been achieved, with very few successful prosecutions. ${ }^{130}$

While the problem of child soldiering is undoubtedly serious, it represents only a fraction of the violations suffered by children during conflict. It might therefore be argued that there is currently something of an over focus on children who soldier, with the result that only a small percentage of children experience criminal justice for the crimes committed against them. Commentators have called for more systematic investigation of the extent to which children are victimized by serious international crimes and prosecution of the full extent of the crimes committed against them. ${ }^{131}$ At the same time, attention has been drawn to the need for criminal justice systems to take active measures to be more accessible to children. Studies show that children and their parents often lack confidence in courts and may avoid them due to security concerns or in order to avoid public scandal, particularly in cases of sexual violence. ${ }^{132}$ It is also essential that where children are involved in criminal proceedings as victims or witnesses child friendly procedures are adopted in order to ensure the right to participation while minimizing distress and preventing retraumatization. ${ }^{133}$

\footnotetext{
${ }^{129}$ See for example, Warrant of Arrest for Ahmad Harun, ICC-02/05-01/07-2, 27 April 2007; Warrant of Arrest for Ali Kushayb, ICC-02/05-01/07-3, 27 April 2007. The Lubanga case remains a disappointment in this regard both in respect of the OTP's failure to charge and the judges' failure to consider the sexual abuse suffered by, particularly girl, child soldiers. The exception is the judgment of Judge Odio Benito. See Prosecutor v. Thomas Lubanga Dyilo, (n 129), Separate and Dissenting Opinion of Judge Odio Benito, para 20. See also Solange Mouthaan, 'Pregnant, Barefoot and in the Kitchen: Am I a Child Soldier Too?' (2014) Women's Studies International Forum.

${ }^{130}$ United Nations Secretary-General, Implementation of the World Programme of Action for Youth: Progress and Constraints with Respect to the Well-Being of Youth and Their Role in Civil Society. UN Doc. A/64/61-E/2009/3, Oct. 30, 2008,12.

${ }^{131}$ See for example Aptel (n 121) 96.

${ }^{132}$ Aptel and Ladisch (n 100) 21.

${ }^{133}$ Stuart Beresford, 'Child Witnesses and the International Criminal Justice System: Does the International Criminal Court Protect the Most Vulnerable?' (2005) 3 Journal of International Criminal Justice 721.
} 
The scope and modalities of prosecuting crimes against children must therefore be strengthened if children are to experience a sense of justice and the betrayal many feel towards adults who exploited and abused them is to be remedied. Only if prosecution is inclusive of all child experiences can it serve effectively as a means of building resilience in post-conflict disaster contexts. ${ }^{134}$ Nevertheless, the violations which are perhaps most widely experienced by children during and post conflict, such as deprivation of food and lack of sanitation, adequate housing, health care and education, are of an economic and social nature, and these violations will not be the subject of international prosecutions.

\subsection{Truth Commissions}

Truth commissions ${ }^{135}$ are also considered an important element of transitional justice. Although their primary purpose is to compile a historical record, their focus on victims and generation of public discussion on accountability and social reform can build capacity for active citizenship and democratic process. Their use of the historical record to inform the development of recommendations for reform can make a valuable contribution to strengthening the rule of law and, therefore, to building resilience in post conflict states. ${ }^{136}$ As well as possessing a right to be considered and

\footnotetext{
${ }^{134}$ Transitional justice programmes must also consider how best to deal with children who have committed serious crimes during conflict. See Aptel (n 121) 98-107 and David Nosworthy, 'Children and Security Sector Governance', in Schnabel (n 6) 133-154.

${ }^{135}$ For definitions of truth commissions see: Eric Wiebelhaus-Brahm, Truth Commissions and Transitional Societies: The Impact on Human Rights and Democracy, (Routledge, 2010), 3-4; Mark Freeman, Truth Commissions and Procedural Fairness (CUP 2006), 12-18; Priscilla B Hayner, Unspeakable Truths: Transitional Justice and the Challenge of Truth Commissions, $\left(2^{\text {nd }}\right.$ edn.) (Routledge, 2010) 11.

${ }^{136}$ Pablo De Greiff, 'Truth Telling and the Rule of Law', in Tristan Anne Borer, (ed), Telling the Truths: Truth Telling and Peace Building in Post-Conflict Societies, (University of Notre Dame Press 2006), 188.
} 
to express their views in these processes, studies show that the perspectives and experiences of children can be a valuable resource in documenting the past and informing the way forward. ${ }^{137}$

Historically, truth commissions, like criminal trials, neither focused on the crimes committed against children nor included children within their processes, instead discussing them largely in connection with violations committed against their parents. Gradually commissions have become more child focused. The South African ${ }^{138}$ and Guatemalan ${ }^{139}$ commissions of the late 1990 s worked to ensure that the impact of past violence upon child populations was documented. However, neither commission allowed children to directly testify or participate in hearings, taking statements instead from representative adults. In 2002, the Sierra Leonean TRC became the first commission with a specific mandate to address violations against children. Children participated in truth seeking through closed and thematic hearings and, with the help of child protection agencies, made an official submission to the TRC, thereby producing the first child friendly version of a truth commission report. The Commission for Liberia, established in 2005, included children systematically within all of its activities and created a task force to develop strategies and procedures to effectively include and protect children within statement taking activities. ${ }^{140}$ Likewise, the Kenyan Commission for Truth, Justice and Reconciliation, created in

\footnotetext{
${ }^{137}$ UNICEF Innocenti Research Centre and International Center for Transitional Justice, Children and Truth Commissions, August 2010.

${ }^{138}$ See Piers Pigou, 'Children and the South African Truth and Reconciliation Commission' in Parmar (n 56).

${ }^{139}$ See Samuel Totten, 'The Plight and Fate of Children vis-à-vis the Guatemalan Genocide', in Samuel Totten (ed) The Plight and Fate of Children During and Following Genocide, (Transaction Publishers 2014), Ch 6.

${ }^{140}$ See Theo Sowa, 'Children and the Liberian Truth and Reconciliation Commission"' in Parmar (n 56).
} 
2008 , treated children as a special group of victims and as participants within truth seeking processes. ${ }^{141}$

Since this time there has been a decline in the inclusion and consultation of children and youth in truth seeking. ${ }^{142}$ This is perhaps symptomatic of a general deterioration of truth seeking standards in recent years ${ }^{143}$ and of the resource and budget implications of systematically including children within truth seeking processes. Yet to overlook children is to hamper the potential of truth seeking mechanisms to deliver transitional justice objectives and limits the possibilities for transitional justice mechanisms to build resilience to future conflict related disasters. Past commissions have not only documented the full nature, extent and consequences of violations against children, ${ }^{144}$ they have identified the structural causes of abuse and formulated recommendations on how systems can be strengthened and repetition avoided. The South African TRC, having found that the children and youth had been militarized by the conflict ${ }^{145}$ recommended the creation of community colleges and youth centres to facilitate reintegration and assist with adult education for those who had lost educational opportunities, ${ }^{146}$ as well as advising on the creation of a Peace Corps. ${ }^{147}$ The Sierra Leonean TRC documented a culture of physical and sexual violence against children during the civil war and as a remedy recommended

\footnotetext{
${ }^{141}$ Christopher Gitari Ndungú, Lessons to be Learned: An Analysis of the Final Report of Kenya's Truth, Justice and Reconciliation Commission, International Center for Transitional Justice, May 2014, 7-8.

${ }^{142}$ See for example, "Ivorian Youth Find New Ways to be Heard on Truth, Justice and the Future of their Country", International Center for Transitional Justice, May 2014 and Aptel and Ladisch (n 100) 13-14 on the failure to acknowledge children in the Nepalese legislation.

${ }^{143}$ See Alison Bisset, 'The Role of Truth Commissions in Adjudicating Human Rights Violations', in James A Green and Christopher PM Waters, (eds) Adjudicating International Human Rights: Essays in Honour of Sandy Ghandhi, (Brill: Nijhoff 2014).

${ }^{144}$ See for example, Truth and Reconciliation Commission of South Africa Report (2002), Vol. 4, Ch. 9; Chega!, Report of the Commission for Reception, Truth and Reconciliation for East Timor (2006), Ch 7.8 .

${ }^{145}$ Truth and Reconciliation Commission of South Africa Report, ibid, Vol 5, Ch 6.

${ }^{146}$ Ibid.

${ }^{147}$ Ibid Vol 5, Ch 8.
} 
prohibition of the corporal punishment of children and the introduction of peace studies in school curricula. ${ }^{148}$ In Liberia, the Commission uncovered serious violations of children's civil, political, economic and social rights, ${ }^{149}$ leading it to call for the passing of a comprehensive child-friendly legal framework and an Act imposing responsibility for monitoring its implementation upon the National Human Rights Commission. ${ }^{150}$ Many commissions have called for educational sector reform and curriculum revision, viewing it as a means of addressing the legacies of conflict and inculcating a human rights culture. ${ }^{151}$

Lack of political will, minimal resources and limited institutional capacity have frequently made implementation challenging in post-conflict contexts. ${ }^{152}$ It is easy for governments to overlook recommendations relating to children as they are a frequently disenfranchised group. It has therefore been suggested that in order to maximize the potential impact of truth commission recommendations and enhance the likelihood of their implementation, commissions should frame their recommendations in "rights" language, especially where these recommendations have an economic and social dimension. ${ }^{153}$ This turns economic needs into a state obligation, rather than a gesture of charity, and provides civil society, to whom lobbying for implementation often falls, with a more powerful platform from which to argue for reform and investment. By engaging with economic and social rights as such, truth commissions

\footnotetext{
148 Witness to Truth: Report of the Sierra Leone Truth and Reconciliation Commission, (2004), Vol 2, Ch 3, paras 88-94.

${ }^{149}$ Final Report of the TRC of Liberia (2009).

${ }^{150}$ Ibid, Vol 3, Title II, 106.

${ }^{151}$ On the striking example of Peru see Julia Paulson, 'Truth Commissions and National Curricula: The Case of Recordándonos in Peru"'in Parmar (n 56) 327. On the role of education in peacebuilding see Elizabeth A Cole, 'Transitional Justice and the Reform of History Education' (2007) 1 International Journal of Transitional Justice 115; Julia Paulson, (Re)Creating Education in Post-Conflict Contexts: Transitional Justice, Education and Human Development, (International Center for Transitional Justice 2009).

${ }^{152}$ On the problems of implementation see Hayner (n 135) 190-5.

${ }^{153}$ Laplante (n 91) 351.
} 
can additionally complement the right to development, which in turn can act as a method of enhancing resilience to future conflict related disasters. ${ }^{154}$

\subsection{Reparations}

A further transitional justice mechanism with a role to play in addressing the violations of the past and charting a way forward to a peaceful future is reparations. Under international law, victims of gross human rights violations, including child victims, have a right to reparation. ${ }^{155}$ In post-conflict contexts, reparations are important. They acknowledge the violations committed against victims, seek to establish their equal citizenship within society and aim to rebuild trust among citizens and between citizens and public institutions. ${ }^{156}$ They do so by demonstrating that past abuses are taken seriously and that the government is committed to making a contribution to the survivors' quality of life. ${ }^{157}$ In relation to children, they serve an important function in signaling that past modes of operation will not be tolerated and help children to understand their place in a society based on rights, rather than violence. ${ }^{158}$ Yet as with other transitional justice mechanisms, reparations packages have, to date, been inconsistent in their acknowledgement of violations against

\footnotetext{
${ }^{154}$ Prevention of Armed Conflict: Report of the Secretary-General, UN Doc. A/55/985-S/2001/574, (7 June 2001), para 114; A More Secure World: Our Shared Responsibility: Report of the SecretaryGeneral's High-Level Panel on Threats, Challenges and Change (UN 2004).

${ }^{155}$ See generally, International Covenant on Civil and Political Rights, General Assembly Resolution 2200A (XXI), 16 December 1966, entered into force 23 May 1976, Art 2(3); Bassiouni Principles, (n 82). On child victims specifically see, UN Guidelines on Justice in Matters Involving Child Victims and Witnesses of Crime, ECOSOC Resolution 2005/20, 22 July 2005; UNCRC Art. 39.

${ }^{156}$ Lisa Magarrell, Reparations in Theory and Practice, International Center for Transitional Justice, October 2007.

${ }^{157}$ Dyan Mazurana and Carlson Khristopher, 'Reparations as a Means for Recognizing and Addressing Crimes and Grave Rights Violations against Girls and Boys during Situations of Armed Conflict and under Authoritarian and Dictatorial Regimes', in Ruth Rubio Marin (ed), The Gender of Reparations: Unsettling Sexual Hierarchies while Redressing Human Rights Violations, (CUP 2009), 162-214. ${ }^{158}$ Aptel and Ladisch (n 100) 26-7.
} 
children, focusing either on victims against parents which indirectly impact children or on a narrow range of particular violations committed against children. ${ }^{159}$

Overlooking children as a group fails to acknowledge their capacity as political actors and agents and their status as rights holders, as well as their significance in building resilience to future conflict.

Future reparations packages should be informed by a broad consideration of the nature of the violations committed and the consequences that flow from them, undertaken in consultation with children themselves. ${ }^{160}$ Reparations might be material and include financial compensation and service packages including access to health care and psychological support, access to education and training and the provision of housing. They may also be symbolic and focus on the provision of public apologies, the erection of memorials and monuments, or the creation of learning centres and museums. ${ }^{161}$ To be most effective, it is believed that reparations should have both symbolic and material elements. ${ }^{162}$ Eligibility should be neither so broad that it fails to recognise those most affected by the most serious crimes, nor so narrow that the majority are excluded. ${ }^{163}$ While post-conflict states are admittedly resource constrained, funding for reparations for children should be a government priority and should not be treated as a substitute for adequate state services, which are the right of all children. ${ }^{164}$ Reparations schemes must additionally be accompanied by effective outreach programmes so that all those eligible are informed and able to apply. ${ }^{165}$ If

\footnotetext{
${ }^{159}$ Ibid 26. See also S Marie Miano, 'Towards a Child Oriented Approach to Reparations: Reflecting on the Rights and Needs of Child Victims of Armed Conflict', (2013) XXVIII Praxis The Fletcher Journal of Human Security 28.

${ }^{160}$ Art 12 UNCRC.

161 Children and Truth Commissions (n 137) 51-7.

162 Magarrell (n 156) 5.

163 Children and Truth Commissions (n 137) 53-4.

164 Ibid 55-6.

165 Ibid.
} 
invested in properly, reparations programmes have the potential to make a positive long-term impact and equip children with the resources and support needed to move forward to a productive life. They can therefore assist in laying the conditions for a peaceful future, contribute to reconstructing post conflict states and building resilience to future conflicts.

\subsection{Institutional Reform}

The final component of transitional justice is institutional reform, which involves reviewing and restructuring state institutions so that they are accountable, operate in accordance with and preserve the rule of law and respect human rights. From a child rights perspective, institutional reform should build a protective environment for children, preventing their abuse and exploitation, and ensure that health and education systems, social welfare institutions and the judiciary, police and security sectors promote children's rights. ${ }^{166}$

Disarmament, demobilization and reintegration schemes are an important element of institutional reform for CAAFAG. They aim to create a clear distinction between civilians and military personnel and to ensure that former combatants do not take up arms again. ${ }^{167}$ Effective disarmament, demobilization and reintegration schemes are important not only because frustrated or marginalized youth can destabilize a fragile peace, but also as a means of providing former child soldiers with

\footnotetext{
166 Ibid 59.

${ }^{167}$ Lars Waldorf, 'Just Peace? Integrating DDR and Transitional Justice', in Lekha Sriram (n 86) 63.
} 
the possibility of playing a constructive role in society. ${ }^{168}$ The "reintegration" element is particularly significant for children. Despite this, studies show that many former child combatants do no go through any sort of disarmament, demobilization and reintegration scheme and where they do, the focus is typically on demobilization and disarmament, with inadequate provision for reintegration. ${ }^{169}$ Girl soldiers are frequently marginalized because they are viewed as less of a security threat than male combatants. They are also more likely to self-demobilize in order to avoid social stigma when they return to their communities or to avoid sexual violence in male dominated demobilization camps. ${ }^{170}$ Research indicates, however, that where children do participate in rehabilitative programmes, it aids their recovery, ${ }^{171}$ suggesting that disarmament, demobilization and reintegration programmes should be a priority in post-conflict states if the possibilities for recovery and a peaceful future are to be realized.

As in other transitional justice mechanisms dealing with CAAFAG is only one component of institutional reform. Legislative reform can serve as an important means of mainstreaming children's rights. A number of transitional states have taken the opportunity to ratify the $\mathrm{CRC},{ }^{172}$ implement national laws that are consistent with CRC principles and promote a focus on children in domestic legal processes. Sierra

\footnotetext{
${ }^{168}$ Roger Duthie and Irma Specht, 'DDR, Transitional Justice and the Reintegration of Child Combatants' in Ana Cutter Patel, Pablo de Greiff and Lars Waldorf (eds), Disarming the Past: Transitional Justice and Ex-Combatants, (Social Sciences Research Council 2010), 194. 169 Ibid 196; Michael Wessels, Child Soldiers: From Violence to Protection, (Harvard University Press 2006), 155.

${ }^{170}$ Luisa Maria Dietrich Ortega, 'Transitional Justice and Female Ex-Combatants: Lessons Learned From International Experience' in Patel, de Greiff and Waldorf (n 168); Beth Verhey, Reaching the Girls: Study on Girls Associated with Armed Forces and Armed Groups in the Democratic Republic of Congo, Save the Children UK and the NGO Group CARE, IFESH and IRC, November 2004.

${ }^{171}$ Peter Uvin and Charles Mironko, 'Western and Local Approaches to Justice in Rwanda,' (2003) 9 Global Governance 226, 229.

172 See for example: Bosnia and Herzegovina, which ratified following conflict in 1993; South Africa, which ratified in 1995 post-apartheid; and Timor Leste, which ratified following independence in 2003.
} 
Leone created a Child Forum Network in 2001 to advocate for children's rights, launched the National Youth Policy in 2003 and passed the Child Rights Act in 2007. ${ }^{173}$ Timor Leste established a National Commission for the Rights of the Child in 2009, appointed Child Protection Officers in all districts and has drafted a Child Code and Juvenile Justice Bill. In Liberia, a Child Protection Network and Children's Parliament have been established and, in 2012, the Children's Act was passed, becoming one of Africa's most comprehensive pieces of child rights legislation. ${ }^{174}$ However, in order for these legislative frameworks to have meaningful impact, they must be accompanied by political commitment to allocate the funding needed to create the supporting infrastructure necessary to implement mechanisms aimed at ensuring children's rights.

Education is also considered key to building resilience. ${ }^{175}$ Training teachers to deliver new curricula based on the lessons of the past and which introduce civic and human rights education, conflict resolution and gender studies can play an important role in social reconstruction, reconciliation and building peace and democracy. ${ }^{176}$ Schools can also play a role in providing training on HIV/AIDS prevention and landmine awareness, which are a threat to children in post-conflict states in the short and longer term. Yet, despite the convincing discourse on the need for educational reform in post conflict contexts, a lack of political will, and sometimes divergent social opinions, has hampered the development and implementation of new curricula.

\footnotetext{
${ }^{173}$ See generally, Government of the Republic of Sierra Leone, Ministry of Social Welfare, Gender and Children's Affairs, <http://mswgca.gov.sl > accessed 28 July 2015.

${ }^{174}$ Ban Al-Dhayi, 'Children's Law Offers Promise and Protection to Liberia's Children', UNICEF, Monrovia, Liberia, 9 February 2012.

175 Aptel and Ladisch (n 100) 34.

${ }^{176}$ Elizabeth A Cole and Karen Murphy, 'History Education Reform, Transitional Justice and Transformation of Identities', in Paige Arthur (ed) Identities in Transition: Challenges for Transitional Justice in Divided Societies, (CUP 2011), 335-6.
} 
Partial progress has been seen in a number of post-conflict states but the wide scale transformation called for in the aftermath of conflict has not been realized. ${ }^{177}$

Like other aspects of transitional justice, progress must be made on postconflict institutional reform for children if the best prospects for building resilience and avoiding return to conflict are to be realized.

\section{Conclusion}

At present, there is no legal regime dedicated to the protection and promotion of children's rights in disasters. Yet, in the context of post-conflict disasters perhaps there should not be a rush to create more law but to focus instead on utilizing and strengthening existing legal frameworks and mechanisms in order to realise their full potential. There is a wealth of international law that aims to protect children during conflict, to ensure their rights to redress for past violations and to promote their rights in post-conflict contexts. It is essential that these standards are adhered to, not only because international law demands it, but because if post-conflict states are to stand the best chances of reconstruction and reconciliation, and resilience to conflict is to be built, the needs, rights and interests of children, as the next generation, must be prioritized.

Transitional justice, based on international human rights norms, can make an important contribution to reconstruction and resilience building in post-conflict

\footnotetext{
${ }^{177}$ For an overview see Children and Truth Commissions (n 137) 61-3.
} 
disaster contexts. Its mechanisms of truth, justice, reparation and reform can provide accountability for the violations for the past, inform the way forward and lay the foundations for a future based on respect for human rights and the rule of law. While there has been some progress on integrating children within these mechanisms, much work remains to be done to ensure a systematic consideration and inclusion of children throughout all transitional justice processes, as well as on mustering the political will necessary to fulfil recommendations.

Alongside the mainstreaming of children's rights within transitional processes, there must be recognition and acknowledgement that the fulfillment of economic and social rights is an essential component of recovery from conflict and of building resilience to future conflict related disasters. Without the creation of state institutions that protect and promote children's rights, provide them with access to health care and deliver education for all, the prospects of creating a generation of children equipped to function as the leaders of the future and build states founded on democracy, respect for the rule of law and social justice and therefore resilient to future conflict will not be realized.

\section{Bibliography}

Aptel C and Ladisch V, Through a New Lens: A Child Sensitive Approach to Transitional Justice, (International Center for Transitional Justice 2011) 
Laplante LJ, 'Transitional Justice and Peacebuilding: Diagnosing and Addressing the Socioeconomic Roots of Violence through a Human Rights Framework' (2008) 2 International Journal of Transitional Justice 331

Parmar S and others (eds) Children and Transitional Justice: Truth Telling, Accountability and Reconciliation, (UNICEF and Human Rights Programme, Harvard Law School, 2010)

Schnabel A and Tanyshalieva A (eds) Escaping Victimhood: Children, Youth and Post-Conflict Peacebuilding (United Nations University Press 2013)

Report of the UN Secretary General on the Rule of Law and Transitional Justice in Conflict and Post Conflict Societies, S/2004/616, 23 August 2004

UNICEF Innocenti Research Centre and International Center for Transitional Justice, Children and Truth Commissions, 2010 